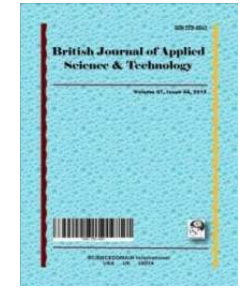

British Journal of Applied Science \& Technology

18(1): 1-8, 2016; Article no.BJAST.16055

ISSN: 2231-0843, NLM ID: 101664541

SCIENCEDOMAIN international

www.sciencedomain.org

\title{
Land Sustainability and Common Property Resources Management in India: Challenges and Prospects
}

\author{
Nazeerudin $^{1 *}$ \\ ${ }^{1}$ Centre for Rural Development Studies, Bangalore University, Bangalore 56, Karnataka, India.
}

Author's contribution

The sole author designed, analyzed and interpreted and prepared the manuscript.

Article Information

DOI: 10.9734/BJAST/2016/16055

Editor(s):

(1) Rares Halbac-Cotoara-Zamfir, Hydrotechnical Engineering Department, "Politehnica" University of Timisoara, Romania.

Reviewers:

(1) Oswell Rusinga, Great Zimbabwe University, Zimbabwe.

(2) Lupala Zacharia, Forestry Training Institute,Tanzania.

(3) Tuneera Bhadauria, Kanpur University, India.

(4) Kabi Prasad Pokhrel, Tribhuvan University, Nepal.

Complete Peer review History: http://www.sciencedomain.org/review-history/16981

Original Research Article

Received $3^{\text {rd }}$ January 2015

Accepted $9^{\text {th }}$ July 2015

Published 21 ${ }^{\text {st }}$ November 2016

\begin{abstract}
Natural resources (land, water, biodiversity and genetic resources, biomass Resources, forests, livestock and fisheries) - the very foundation of human survival, Progress and prosperity, have been degrading fast, and the unprecedented pace of their Erosion is one of the root causes of the agrarian crisis that the country is facing. The Demographic and socio-economic pressures notwithstanding, the unmindful agricultural Intensification, over use of marginal lands, imbalanced use of fertilizers, organic matter Depletion and deteriorating soil health, extensive diversion of prime agricultural lands to Non-agricultural uses, misuse and inefficient use of irrigation water, depleting aquifers, Salanisation of fertile lands and water logging, deforestation, biodiversity loss and genetic Erosion and climate change are the main underlying causes Land distribution is highly skewed, more than 80 per cent of the farmers are small, marginal and sub-marginal and together own about 40 per cent of the total cultivated land, and increasing proportions of the holdings are becoming uneconomical.

In the above back drop, this paper made an attempt to critically examine the inter linkages of issues of natural resources particularly land degradation and livelihood sustainability. It also explore the sustainable land management by Using Common Property Resources efficiently, eco friendly Input technology in Agriculture and Converting Wastelands into Cropped Land.
\end{abstract}


Keywords: Land; degradation; natural resource management; common property resources; sustainable; rural livelihoods.

\section{INTRODUCTION}

Natural resources sustain rural life in several ways. Agriculture sustains a majority of rural Indians who depend on land for cultivation and fodder, forest products for fuel, food and medicine, water for drinking, cooking and irrigation, and fisheries for food and sale. But these resources have been over-exploited and are rapidly depleting, exacerbating already severe rural poverty and vulnerability to climate change. Green revolution policies, for instance, helped India achieve food security. But, aided by subsidies, farmers intensified the use of fertilizers and groundwater irrigation, which has not only degraded land but has also led to the groundwater crisis that now threatens even the basic right to drinking water. Farmers have become caught in a vicious cycle land degradation reduces crop yields so they increase inputs, which in turn raise costs and further degrade land.

Although a piece of land can be used for several purposes in several times the fertility of land must be deteriorated. But it is necessary to maintain the quality of land in the process of economic development. For an individual three basic essential things are required for his survival: food, clothing and shelter. In the primitive community when man lived in jungles he did not have clothing or even shelter [1].

Certain initiatives intended to protect and conserve natural resources, on the other hand, have failed to consider the livelihoods of those critically dependent on those resources. Cultivate 'wastelands 'or acquire local commons for public projects also have alienated communities from common property resources and led to the disintegration of their stake in natural resources. The e preservation of natural resources is essential to securing rural livelihoods. The vicious cycle of degradation and depletion of resources that impacts livelihoods must be reversed, though the zeal to protect resources (such as forests) should not come at the cost of livelihoods.

Conservation and efficient use of natural resources can be achieved through sustainable farming practices such as the use of organic composite fertilizers and reduced water-intensity. This must be encouraged through a mix of financial incentives, technology, regulations and institutional support. Top-down efforts to arrest land degradation and increase agricultural productivity have had limited success. But experience shows that communities, either spontaneously or aided by NGOs, can effectively ensure equitable sharing, conservation and maintenance of natural resources. The success of initiatives such as community managed sustainable agriculture and decentralized rainwater harvesting highlight the importance of a more participatory approach. The importance of community management has now been acknowledged in two legislations-the Panchayats (Extension to Scheduled Areas) Act 1996 and Forest Rights Act 2006-that entrust forest dwellers with certain rights over forests. These Acts must be implemented in letter and spirit. Efforts to address climate change must be integrated into rural development policy. These efforts should address mitigation, such as through organic farming which simultaneously reduces environmental stress and cost of cultivation, and to build the rural population's capacity to adapt and become more resilient to sudden impacts of climate change.

The conservation and wise use of resources are vital to the future of this planet and its inhabitants. And common property resources would continue to be integral components of the earth's ecological and social systems. It is a fact that the present generation live in an age of population growth, technological innovation, and social change. The present enquiry on common property resources (CPRs) and sustainable land management aims at assessing their role in the life and economy of the rural people. In recent years, use of common property resources in India has drawn the attention of planners and policy-makers dealing with wasteland development, antipoverty programs and environmental problems. The Planning Commission, while exploring the prospects and strategies for bio-mass fuel and fodder supplies in the rural areas. Under these circumstances, the present study made an attempt to explore the possible action for sustainability of agriculture in particular and environment in general.

\section{METHODOLOGY}

The study has been carried out both at theoretical as well as empirical levels. An 
intensive review of studies dealing with common property resources as well. The empirical study is based on both primary and secondary data. Secondary data sources include various reports of planning commission and working group reports of agriculture and environment etc.

\subsection{Balancing Livelihoods and Natural Resource Conservation}

Rural India depends heavily on natural resources for sustenance and livelihood. Land is used for cultivation and fodder, wood and other forest products for fuel, food and medicines, crop and animal waste for fuel, water for drinking, cooking and irrigation, and local fisheries for human consumption and export. Products and services derived from natural resources also provide an ever expanding of incomegenerating opportunities, crucial to those who lack adequate employment, particularly during the lean agricultural season. But population growth, market forces andlindustrialization have led to over-exploitation of naturallresources-i.e. use rates exceeding natural regeneration ratesand regeneration or conservation efforts have been inadequate. Environmental degradation, thus, is shrinking the rural economy's input base and exacerbating already severe rural poverty [2] Tensions and conflicts over natural resources are increasing. Steps to ensure the sustainability of natural resources and arrest damage to the ecosystem and rural livelihoods are urgently needed before the situation becomes irreversible.

Past policies governing natural resource use and management often failed, in part because they failed to recognize the importance of natural resources in sustaining rural livelihoods. Only now have we realizedlthat rural development strategies must aim to conserve natural resources, increase efficiency of resource use, reduce negative environmental impacts, and strengthen climate resilience of communities and contribute to climate change mitigation [3] Because most natural resources are communitylowned, local institutions play a critical role in managing them. The capacity of local institutions to plan, Implement and manage resource conservation through various government programmes, such as Mahatma Gandhi National Rural Employment Guarantee Scheme (MGNREGS), thus needs to be strengthened.

\subsection{Concept of Sustainable Land Management}

\subsubsection{Declining land availability}

Land provides habitat and sustenance. But the increased pressure of population growth and competing land uses have caused a serious decline in the availability and quality of land resources with huge impacts on ecological sustainability and rural livelihoods India occupies only 2.4 per cent of the world's area, yet supports 17 per cent (as of 2011) of the world's population and about 11 per cent (as of 2007) of the world's livestock. Over the years, land use has significantly intensified due to population and livestock growth, economic forces, weakening of institutions that regulate land use and various natural factors [4]. This declining land availability has had a major impact on rural livelihoods. Agriculture, the largest category of land use, sustains a majority of the rural population and is the mainstay of the rural economy. Farmers have tried to increase yield or productivity through increased irrigation and use of other inputs, resulting in higher cropping intensity. So, although the net sown area has remained at 46 per cent of total geographic area since 1970-71 (it increased in the first two decades after independence from 42 percent in 1950-51 to 46 per cent3), the gross cropped area has significantly increased due to higher cropping intensity. (See Fig. 1). Industrialization, urbanization and infrastructure projects have also increased the demand for land. The area under non-agricultural use has increased from 16 million hectares (mha) in 1970-71 to 26 mha in 200910 [5]. leading to vast displacement and resettlement. And the history of implementing resettlement and compensation packages for people displaced by land acquisition for nonagricultural purposes is not encouraging. But the Right to Fair Compensation and Transparency in Land Acquisition, Rehabilitation and Resettlement Act 2013-which attempts to balance such concerns with the needs of industrialization and development-offers some relief to those historically dependent on land for their livelihood.

\subsubsection{Land degradation}

Land degradation is the main cause of reduced land potential, which, in turn, affects the livelihoods of those dependent on land. Land degradation reduces crop yields, so they increase the use of farm inputs, which in turn 


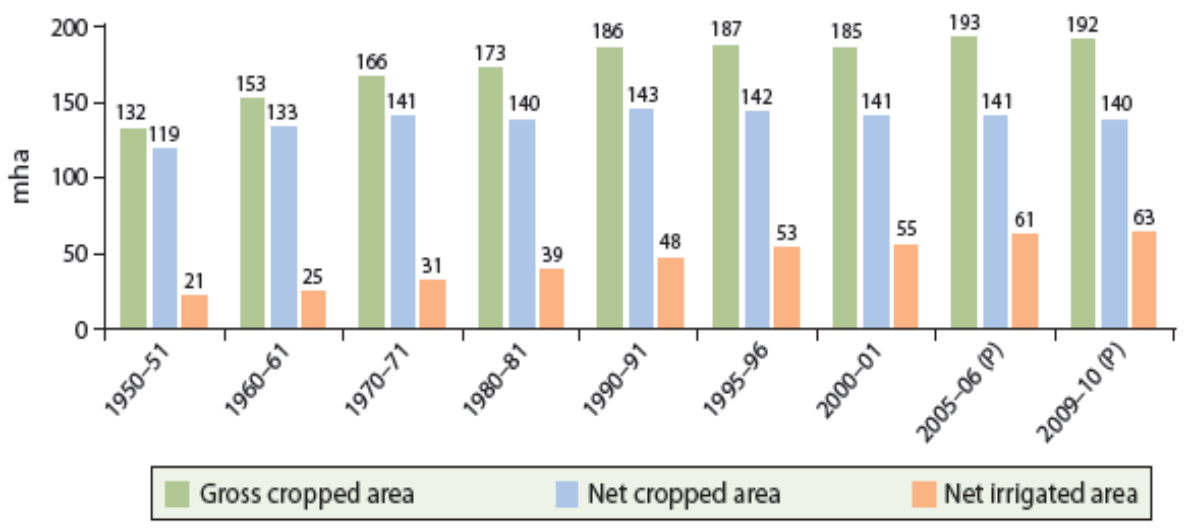

Fig. 1. Gross cropped area, net cropped area and irrigated are Note: P-Provisional; Source: MoA (2012a)

raises costs and contributes to further degradation of the land. Since the minimum support price (MSP) is determined at the national level, farmers in regions with higher cultivation costs suffer more than those in over the years; land use has significantly intensified due to population and livestock growth, economic forces, weakening of institutions that regulate land use and various natural factors.

1. Per capita availability of land declined from 0.89 ha in 1951 to 0.27 ha in 2011 , and is projected to decline to 0.19 ha by 2050 . The average size of operational holdings decreased from 2.3 ha in $1970-71$ to 1.2 ha by 2010-11 [6].

2. Net sown area is the total area sown with crops and orchards with areas sown more than once in the same year counted only once.

3. Land-use statistics are available for 200910 for 306 mha (covering 93 per cent of the total land area).

4. Gross cropped area is the total area sown with areas cropped multiple times counted as many times as they are sown in a year.

5. The cropping intensity represents the ratio of the gross cropped area to the net cropped area.

By far the leading cause of land degradation is soil erosion due to water run-off and loss of vegetation cover. Land degradation reduces crop yields, so they increase input use, which raises costs and further degrades land. Fertile regions. In addition to crop cultivation, land degradation also adversely affects livestock and forest production. In 2005, the National Bureau of Soil Survey and Land Use Planning (NBSS\&LUP),
Nagpur, reported that around 147 mha of land suffered from various kinds of degradation. According to a study by the Indian Space Research Organization (ISRO), as much as 57 per cent of India's total area has been subject to degradation (32 per cent) or desertification (25 per cent), the degradation of dry land areas [7] various factors caused such degradation.

\subsubsection{Soil erosion}

By far the leading cause of land degradation is soil erosion due to water run-off and loss of vegetation cover. In 2008, the NBSS\&LUP estimated that soil erosion by water accounted for 70 per cent of total land degradation In particular, more than half the area of Chhattisgarh, Jharkhand, Madhya Pradesh, Uttar Pradesh, Uttarakhand and the north-eastern hill states has been degraded due to soil erosion, with 11 per cent of the area classified as under very severe soil erosion [8].

\subsubsection{Inappropriate input use}

Land also has been degraded as an unintended consequence of policies that encouraged inappropriate input use. That the green revolution-while it increased output and assisted in attaining self-sufficiency in food grain production using irrigation, high-yielding varieties of seeds, chemical fertilizers and pesticidesalso resulted in inefficient input use and degradation of natural resources is now widely acknowledged.

Fertilizer subsidy has led to a huge increase in fertilizer consumption: from $13 \mathrm{~kg} / \mathrm{ha}$ in the early 


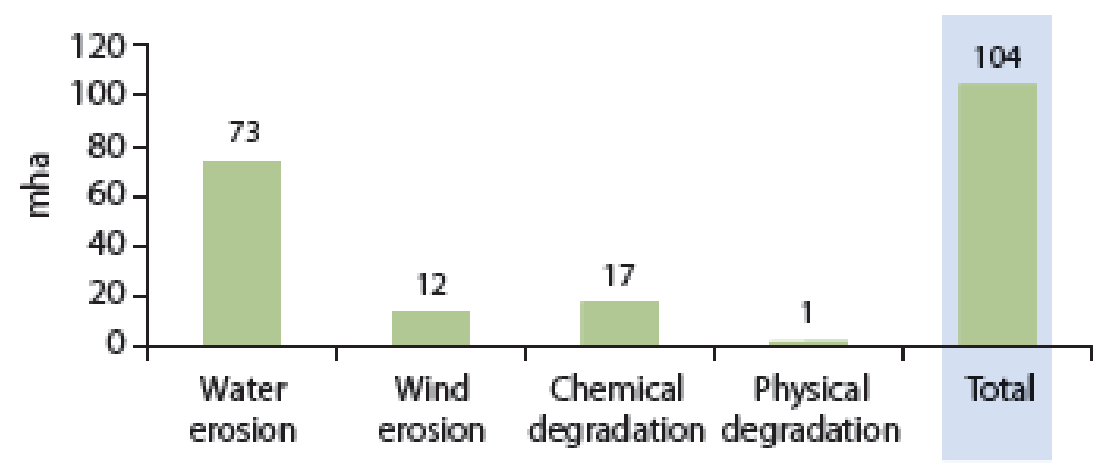

Source: Based on NBSS\&LUP (2008).

Fig. 2. Land degradation

part of the green revolution (1970-71) to 145 $\mathrm{kg} / \mathrm{ha}$ by 2010-11 [9]. The disproportionate use of chemical fertilizers, particularly nitrogen (out of nitrogen, phosphorous and potassium, i.e. N, P, $\mathrm{K})$, has reduced soil nutrients and thereby soil fertility. About 90 per cent of soils are now low to medium in nitrogen, 80 per cent deficient in phosphorus, and 50 per cent deficient in potassium [10].

\subsubsection{Increasing pressure for fodder and fuel wood}

In ecologically fragile arid and semi-arid regions, degradation has also resulted from increasing pressure for fodder and fuel wood on common lands and forests. About 70 per cent of India's geographical area is categorized as dry land (16 per cent arid, 37 per cent semi-arid and 17 per cent dry sub-humid). These areas not only have uncertain water availability but also a restricted natural resource base that offers limited livelihood options. Communities in these regions have evolved survival strategies, but desertification is a growing concern. Changes in frequency and amount of rainfall, reduction in vegetal cover, inappropriate agricultural practices, over-exploitation of natural resources and excessive grazing have resulted in 25 per cent of land undergoing desertification [11]. Land also has been degraded as an unintended consequence of policies that encouraged inappropriate input use.

\subsubsection{Common property resources}

In addition to individual land plots, common or community lands have also undergone degradation. Common property resources (CPRs) - most prominent in arid, mountainous and rain fed areas where agriculture poses high risks [12]. Play an important role in rural life and economy. On average, about 48 per cent of rural households collect materials from CPRs, mostly fuel wood, and the livestock of 20 per cent of households graze on CPRs [13]. Almost 15 percent of India's total area falls under CPRs, but the per capita and per household common property land resources are low at about 0.06 ha and 0.31 ha respectively. Over time, there has been a substantial decline in the area and the quality of CPRs. A study across 80 villages in six states found that between the early 1950s and mid-1980s, the area under CPRs declined by as much as 31 to 55 per cent [14]. This has severe consequences on the poor who lack other income-generation options and depend heavily on CPRs for their livelihood. Judicious management of CPRs, including forests, could also play an important role in arresting water and wind erosion that account for a majority of land degradation.

These common lands were often of poor quality, more suited to natural vegetation and therefore low yielding and requiring significant investment to develop and, over time, between 23 and 45 per cent of the poor households to lease our or sell their land [15]. About 48 per cent of households collect materials from CPRs, mostly fuel wood, and the livestock of 20 per cent of households graze on CPRs. There are wide variations in CPR availability; for example, per household availability of CPRs in Mizoram is more than the area owned per household. 


\section{Use of Common Property Resources}

\begin{tabular}{lr}
\hline Item & Estimate \\
\hline $\begin{array}{l}\text { Households reporting collection of any material from CPRs } \\
\quad \text { of which: collection of fuel wood }\end{array}$ & $48 \%$ \\
\hline $\begin{array}{l}\text { Average value of annual collections per household } \\
\text { Ratio of average value of collection to average of consumption expenditure }\end{array}$ & $45 \%$ \\
\hline Households reporting grazing of livestock on CPRs & 393 \\
\hline $\begin{array}{l}\text { Households reporting use of common water resources for: } \\
\text { l. Irrigation }\end{array}$ & $20 \%$ \\
Ii. Livestock rearing & $23 \%$ \\
iii. Household enterprise & $30 \%$ \\
IV. Fishing & $2.8 \%$ \\
\hline $\begin{array}{l}\text { Note: CPRs include village pastures and grazing grounds, village forests, protected and unclassified government forests, wastelands, watershed } \\
\text { drainage, ponds, rivers, tanks, reservoirs, canals, and irrigation channels. }\end{array}$ & \\
Source: NSSO (1999). &
\end{tabular}

\footnotetext{
${ }^{6}$ There are wide variations in CPR availability; for example, per household availability of CPRs in Mizoram is more than the area owned
} per household

\section{MANAGEMENT EFFORTS}

\subsection{Converting Wastelands into Cropped Land}

Both the central government and some state governments have tried to bring marginal lands unsuitable for food production under productive use. Many wastelands were cultivated with jatropha and pongamia that produce oil, which can be used as bio-diesel, using limited water, nutrients and capital. From an equity perspective, the conversion of wastelands into cropped land reduces availability of village commons and also denies pastoralists grazing lands which, though degraded, support their livelihood [16]. Since then, watershed development and other efforts to bring wasteland under cultivation - such as, creating additional water bodies in wastelands under the MGNREGS and regenerating forest land in some states-have helped further reduce wastelands to 14.75 per cent of the total area in 2008-09 [17]. (see Fig. 3). But because about two-thirds of this decrease is due to the conversion of wastelands into cropped area and plantations, the disappearance of the commons emerges as a concern.

\subsection{Watershed Experiences}

Efforts to arrest land degradation and increase agricultural productivity have taken a watershed approach, particularly in rain fed and resourcepoor areas. Such an approach works towards conservation, regeneration and judicious use of natural resources. The programmes that adopted such an approach aimed to improve water conditions, soil fertility and crop productivity, and reduce erosion in cropped areas, while promoting socio-economic development in these resource-poor areas. Interventions under such programmes involved construction of structures to prevent soil erosion (such as vegetative barriers, contour bunds and small waterharvesting structures), changes in agricultural practices (such as in-situ soil and moisture conservation), agro-forestry, pasture development and horticulture. But watershed programmes that largely took a top down approach and focused mainly on engineering and construction activities, without community participation, have had limited success. Because they originated from initiatives that protected dams from silting, they had a conservation bias and followed a 'ridge-to-valley approach' that neglected livelihoods and lacked clear development goals [18]. Community participation was generally low, and user groups and community based organizations often became inactive after project were completed. Maintenance in the postimplementation phase accordingly was poor, and often led to siltation, damage and leakage in some watersheds. The government consolidated the three watershed programmes into the Integrated Watershed Management Programme (IWMP) in 2009. The IWMP aims to grant greater flexibility in project selection and envisages greater community participation in planning and executing watershed development programmes. 


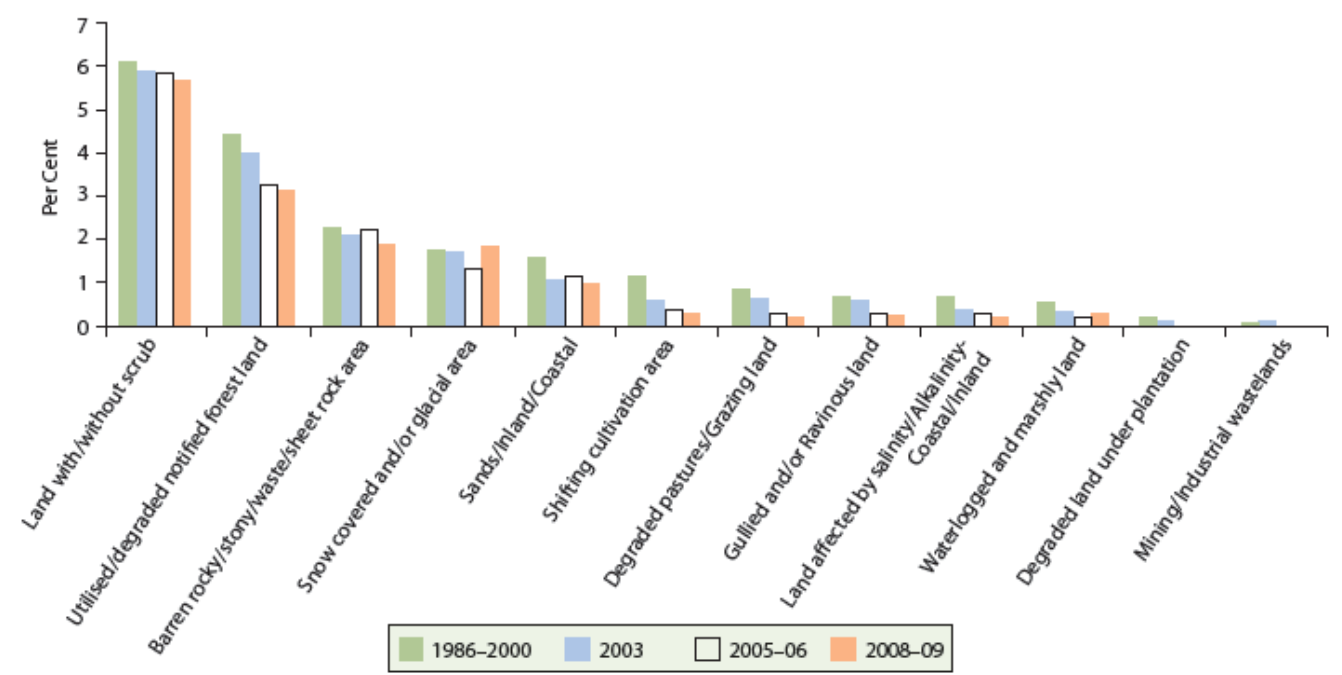

Source: Based on MoRD and NRSC (2010, 2011) and http://dolr.nic.in/dolr/wasteland_atlas.asp (accessed in 2013).

\footnotetext{
${ }^{7}$ Grasslands may be dearings within or around forests. Natural grassland is defined as plant community in which the dominant species are perennial grasses with few or no shrubs and trees (Misri and Singh 1995: 61).
}

Fig. 3. Share of Wastelands $\mathrm{n}$ total geographical area

\subsection{Judicious Input Use in Agriculture}

Green revolution policies ignored soil health by subsidizing chemical fertilizers. In 2010, the government moved from a regime of subsidy per fertilizer product to a regime of nutrient-based subsidy (NBS). Under NBS, the government subsidizes each macronutrient ( $\mathrm{P}$ and $\mathrm{K})$, a secondary nutrient (sulphur) and two micronutrients (zinc and boron). After the introduction of NBS, prices of $\mathrm{P}$ and $\mathrm{K}$ fertilizers increased significantly.

But NBS does not include urea, the main source of $\mathrm{N}$. While the global urea price averaged 80 per cent of the wheat price during 1980-2005, and is presently around 150 per cent, the urea price in India consistently declined from over 150 per cent of the wheat MSP in the 1980s to about 40 per cent at present [19]. Efforts are now underway to promote sustainable farming methods to rectify the negative effect of these inputs. Organic farming first received attention in 2004-05 with the introduction of the National Project on Organic Farming (NPOF). The government has promoted organic farming through NPOF along with the National Horticulture Mission, the National Project on Management of Soil Health and Fertility and the Rashtriya Krishi Vikas Yojana, by providing financial assistance for the creation of compost units and bio-fertilizer and bio-pesticide production units and compensating farmers for a part of cultivation costs.

As a consequence, between 2004-05 and 2010 there was a twenty-five-fold increase in the area certified under organic farming. But organic farming still accounts for less than 1 per cent of India's total cultivated area (PIB n.d.). Sikkim has made marked progress and has already brought 40 per cent of its total cultivated land under organic farming, with the intention of bringing the entire state under organic farming by eco-friendly methods have brought them better returns. Recognizing the benefits, including lower expenditure on chemical fertilizers and pesticides, reduced water requirements coupled with consistent higher yields, many states have adopted sustainable farming practices. The National Rural Livelihoods Mission also has a component on promoting sustainable agricultural methods.

\section{CONCLUSION}

The challenge is to foster development that is technically sound, culturally acceptable, and economically viable. Considering the issues of sustainability, global warming, land degradation, livelihood of the rural poor, sustaining productivity of agriculture and availability of natural resource in India. 
Achieving sustainable land use with very marginal groups in Indian society is not at all easy. There are considerable constraints in all domains from environmental, socio-economic, socio-cultural and organizational, to constraints at government policy levels.

However, the long-term processes started by the NGOs in the sustainable natural resources management in general and common property resources in particular could be seen both in social and political awareness raising, claim making capacity and sustainable land use needs important support from Central and State Governments in India.

It is noted that to some extent NSSO provides raw data to analyze its secondary datasets which need to be supplemented by more case studies that allow us to understand CPR use in the context of different agricultural systems in the country.

\section{COMPETING INTERESTS}

Author has declared that no competing interests exist.

\section{REFERENCES}

1. Bairagya R, Sarkhel J. Food crisis and sustainable food security in India. European Journal of Business and Management. 2011;3(10):77-85.

Available:www.iiste.org

(Accessed in November 2011)

2. Jodha NS. Common property resources and the dynamics of rural poverty: Field evidence from dry Regions of India. In Economics of Forestry and Rural development - An Empirical Introduction from Asia, (eds.) Hyde and Amacher, University of Michigan Press, USA; 2000.

3. Rural development [MoRD]. 2012. Annual Report 2011-12 SSS. MoRD, New Delhi.

4. Rural development [MoRD]. Annual Report 2011-12 MoRD, New Delhi; 2012.
5. Rural development [MoRD]. Annual Report 2011-12S. MoRD, New Delhi; 2012.

6. Rural development [MoRD]. Annual Report 2011-12. MoRD, New Delhi; 2012.

7. Ajai AS, Arya PS, Dhinwa SK, Pathan, Ganesh Raj K. 'Desertification/ land degradation status mapping of India. Current Science. 2009;97(10):1478-83

8. National Academy of Agricultural Sciences (NAAS). 2012-13.

9. National Academy of Agricultural Sciences (NAAS); 2012-13.

10. Rural development [MoRD]. 2012. Annual Report 2011-12SSS. MoRD, New Delhi.

11. Ajai AS, Arya PS, Dhinwa SK, Pathan, Ganesh Raj K. Desertification/ land degradation status mapping of India. Current Science. 2009;97(10):1478-83.

12. Agarwal A, Narain S. Towards green villages: A strategy for environmentally sound and participatory rural development (New Delhi: Centre for Science and Development; 1989.

13. NSSO. Employment and unemployment situation in India, 2009-10. NSS 66th Round. Report Number 537. New Delhi: Ministry of Statistics and Programme Implementation, Government of India; 2011.

14. Jodha, Narpat S. Common property resources and rural poor in dry regions of India'. Economic and Political Weekly. 1986;1995:21(27):1169-81.

15. Jodha Narpat S. Common property resources and rural poor in dry regions of India'. Economic and Political Weekly. 1986;1995:21(27):1169-81.

16. India National Remote Sensing Center; 2010.

17. Ministry of Agriculture, Government of India National Remote Sensing Center; 2011.

18. Planning Commission, Government of India. 'Press Note on Poverty Estimates, 2009-10'. New Delhi: Government of India; 2012.

19. Planning Commission. Government of India; 2013.

(C) 2016 Nazeerudin; This is an Open Access article distributed under the terms of the Creative Commons Attribution License (http://creativecommons.org/licenses/by/4.0), which permits unrestricted use, distribution, and reproduction in any medium, provided the original work is properly cited.

Peer-review history:

The peer review history for this paper can be accessed here: http://sciencedomain.org/review-history/16981 